\title{
Two new species of the genus Docosia Winnertz (Diptera: Mycetophilidae) from Russia and Turkmenistan
}

\author{
Ава новых вида рода Docosia Winnertz (Diptera: Mycetophilidae) \\ из России и Туркменистана
}

\begin{abstract}
A.I. Zaitzev
А.И. Зайџев

Moscow City Pedagogical University, Institute of Natural Sciences, Department of Animal and Plant Biology, Chechulina str. 1, Moscow 111568, Russia. E-mail: azaitzev@mail.ru

Московский городской педагогический университет, Институт естественных наук, кафедра биологии животных и растений, ул. Чечулина 1, Москва 111568, Россия
\end{abstract}

KEYWORDS: Diptera, Mycetophilidae, Docosia, Russia, Turkmenistan, taxonomy, description, new species КЛЮЧЕВЫЕ СЛОВА: Diptera, Mycetophilidae, Docosia, Россия, Туркменистан, таксономия, описание, новый вид.

ABSTRACT. Two new species of Docosia Winnertz, 1863 - Docosia helveoloides and D. turkmenica spp.n. are described from Astrakhan region (Russia) and Turkmenistan. Illustrations of male terminalia are provided.

РЕЗЮМЕ. Приводятся описания двух новых видов грибных комаров рода Docosia Winnertz, 1863 Docosia helveoloides и D. turkmenica spp.n. из Астраханской обл. России и из Туркменистана с иллюстрациями терминалий самцов.

\section{Introduction}

Until recently genus Docosia Winnertz, 1863 was rather poor studied group of Mycetophilidae. In the catalogue of Palaearctic Diptera Hackman designated only 16 species [Hackman, 1988]. In less than 20 years the number of species increases in more than two times because of several important works [Chandler, 1994; Chandler et al., 2006; Kurina, 2006; Laštovka, Ševčik, 2006; Xu et al., 2003, 2005]. During the revision of the material collected by the author in Turkmenistan and by S.A. Kapralov in Astrakhan region of Russia two new Docosia species were found. Their description is given below.

\section{Material and methods}

The material was collected in Astrakhan region by S.A. Kapralov and in Turkmenistan by the author. Male terminalia were detached and heated in $10 \% \mathrm{KOH}$ solution, neutralized by a solution of acetic acid, washed in water and then stored in glycerine. The morphological terms used here mainly follow Søli [1997]. Type material is deposited in the Zoological Museum of Moscow State University (ZMUM).

\section{Species description}

Docosia helveoloides Zaitzev sp.n.

Figs 1-3.

MATERIAL EXAMINED. Holotype $\sigma^{7}$, RUSSIA: Astrakhan region, Akhtuba Distr., Baskunchak Lake, 4.V.2010, Kapralov leg. (in ethanol). Paratypes: $3 O^{7} O^{7}$, same as holotype (ZMUM).

DESCRIPTION. Male. General dark brown, wing length 2.7-2.9 mm.

Head dark brown with pale setae. Mouthparts dark brown, two basal palpal segments brown, other yelow. Antenna uniformly dark brown. Sixth flagelomere 1.7 times as long as wide.

Thorax entirely dark brown. Mesonotum covered with pale setae. Scutellum with two strong and four much weaker bristles. Propleuron with two strong bristles. Laterotergite bare.

Wings hyaline. Radial veins and rm brownish, other veins pale yellowish. M-stem and basal parts of $M_{1}$ and $M_{2}$ very faint. $R_{1}, R_{5}, r m, M_{1}, M_{2}$, stem of $M_{3+4}+\mathrm{Cu}_{1}, M_{3+4}, \mathrm{Cu}_{1}$ and $\mathrm{A}$ setose. Stem of M-fork 1.2 times as long as rm. Haltere pale yellow.

Legs. Coxae pale yellow with darkened basal parts. Femora yellow. Tibia and tarsi brownish. Mid tibia with 3-4 a, 34 d, 2 p, 4 v. Hind tibia with $6-10$ a, 5-6 d, 3-5 p, 2-3 v. Ratio of tibia to first tarsomere for front, mid and hind legs: 1.2 $1.3,1.3-1.4,1.6-1.7$.

Abdomen dark brown. Tergite IX ovate. Cerci with 7 combs. Ventral lobe of gonostylus bifurcate, dorsal lobe with numerous short spines in apical half.

Female. Unknown.

BIOLOGY. Unknown.

ETYMOLOGY. The species' name indicates its resemblance to $D$. helveola Chandler.

DIAGNOSIS. The new species most closely resembles D. helveola Chandler described from Israel [Chandler, 1994], but differs by the ovoid tergite IX, the structure of gonostylus and aedeagus; male cerci with 7 combs, while they are with 14 combs in D. helveola. 
Docosia turkmenica Zaitzev sp.n. Figs 4-6.

MATERIAL EXAMINED. Holotype $\sigma^{7}$, TURKMENISTAN: Kara-Kala Distr., 11.IV.1989, A. Zaitzev leg. (dry-mounted, glued

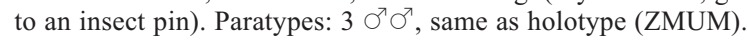

DESCRIPTION. Male. General black, wing length $2.7-$ $3.19 \mathrm{~mm}$.
Head black with numerous pale setae. Mouthparts dark brown, palps yellow, the first palpal segment slightly darkened at least at the basal half. Antenna uniformly dark brown. Sixth flagelomere 1.5 times as long as wide.

Thorax entirely black. Mesonotum shining black covered with pale bristles and scattered with yellowish white setae. Scutellum with two strong and four much weaker

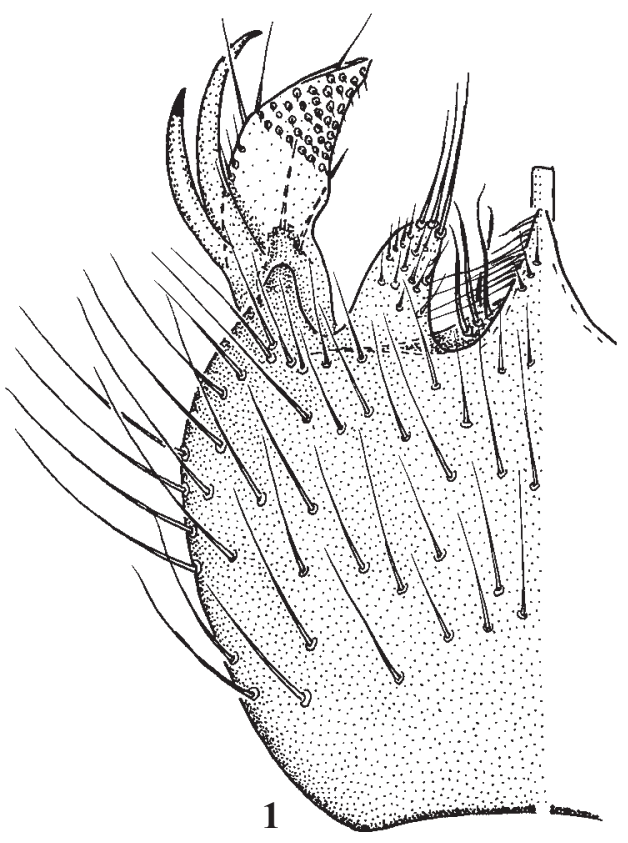

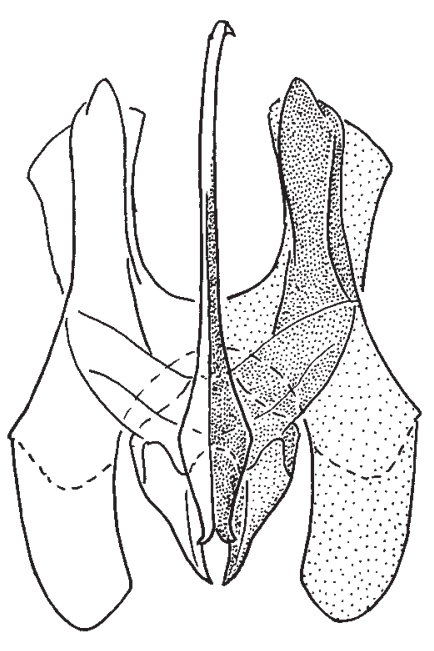

2

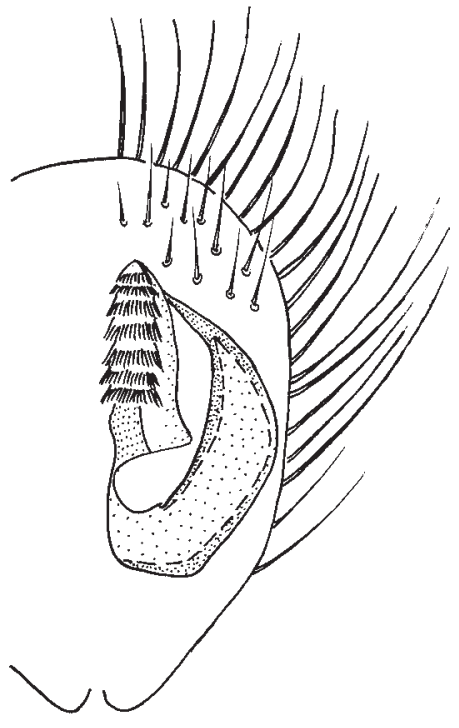

3

Figs 1-3. Docosia helveoloides sp.n.: 1 - male terminalia; 2 - aedeagus; 3 - tergite IX; 1,3 - ventral view.

Рис. 1-3. Docosia helveoloides sp.n.: 1 - терминалии самца; 2 - эдеагус; 3 - IX тергит; 1, 3 - снизу.
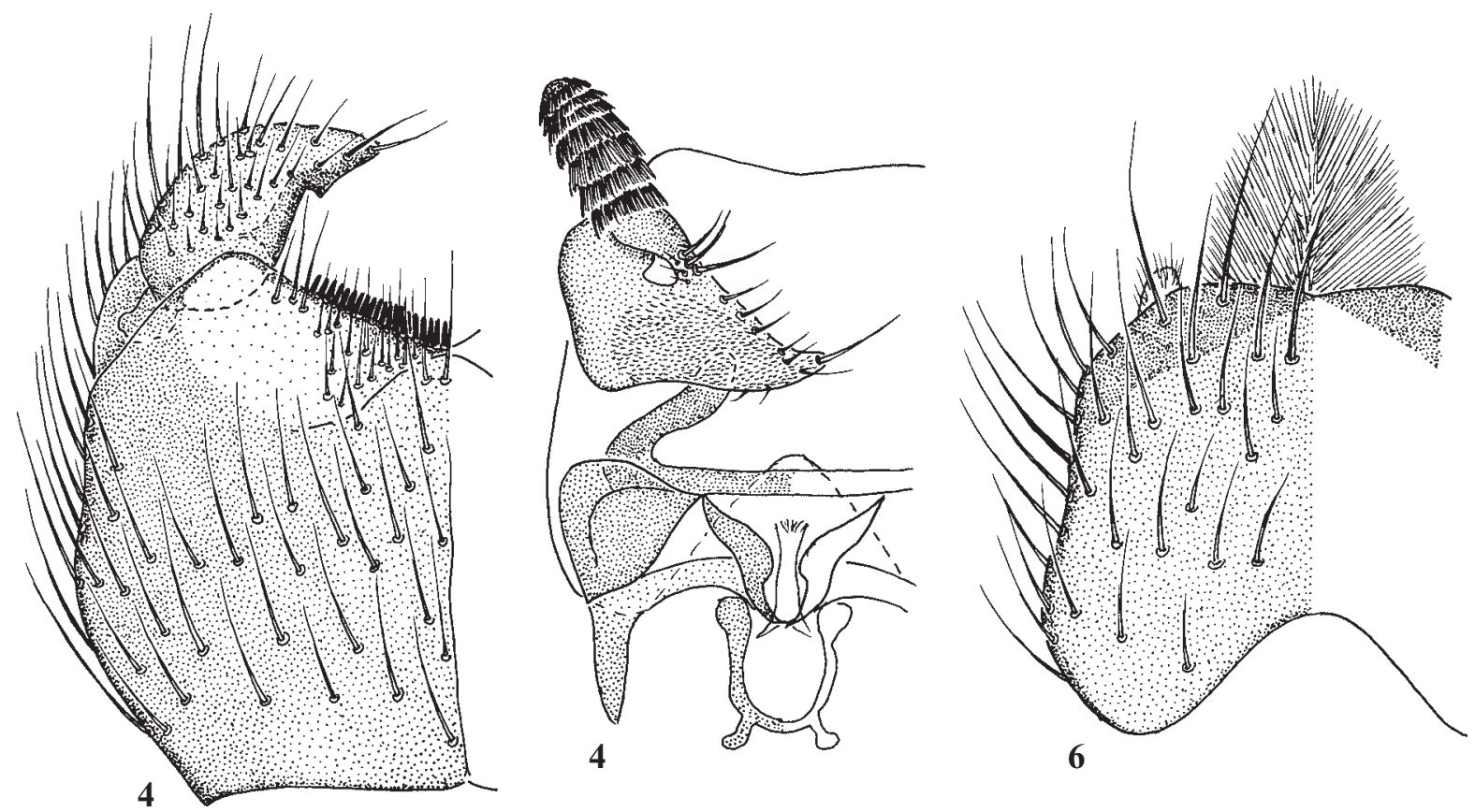

Figs 4-6. Docosia turkmenica sp.n.: 4 - male terminalia; 5 - tergite IX and aedeagus; 6 - tergite IX; 5-6 - ventral view; 7 - dorsal view. Рис. 1-3. Docosia helveoloides sp.n.: 4 — терминалии самца; 5 - IX тергит и эдеагус; 6 - IX тергит; 5-6 - снизу; 7 - сверху. 
bristles. Propleuron with two strong bristles. Laterotergite bare.

Wings hyaline. Radial veins and rm brown, other veins pale yellowish. M-stem and basal parts of $M_{2}$ very faint. $R_{1}$, $\mathrm{R}_{5}, \mathrm{rm}, \mathrm{M}_{1}, \mathrm{M}_{2}$, stem of $\mathrm{M}_{3+4}+\mathrm{Cu}_{1}, \mathrm{M}_{3+4}, \mathrm{Cu}_{1}$ and A setose. Stem of M-fork 1.3 times as long as rm. Haltere pale yellow.

Legs. Fore coxa yellow with black basal part; mid and hind coxae black. Femora yellow; hind femur darkened apically. Tibia and tarsi brownish. Mid tibia with 3-4 a, 3-4 d, $2-3$ p , 3-5 v. Hind tibia with $9-13$ a , 7-8 d, 3-4. Ratio of tibia to first tarsomere for front, mid and hind legs: 1.2-1.3, 1.3$1.4,1.7-1.8$.

Abdomen entirely black. Terminalia dark brown. The apical margin of tergite IX with emargination. Cerci with 7 combs. Gonocoxites with distinct apical emargination and with numerous black spines.

Female. Unknown.

BIOLOGY. Unknown.

ETYMOLOGY. The species' name indicates the first record being from Turkmenistan.

DIAGNOSIS. The new species resembles $D$. carbonaria Edwards, 1941, but differs clearly in the form of gonostylus and tergite IX.

ACKNOWLEDGEMENTS. I thank Mr. S. A. Kapralov (Lobachevsky State University of Nozhni Novgorod, Russia) for providing me with the material of Mycetophilidae from Astrakhan region.

\section{References}

Chandler P. 1994. The fungus gnats of Israel (Diptera: Sciaroidea, excluding Sciaridae) // Israel Journal of Entomology. Vol.28. P.1-100.

Chandler P.J., Bechev D.N., Caspers N. 2006. The fungus gnats (Diptera: Bolitophilidae, Diadocidiidae, Ditomyiidae, Keroplatidae and Mycetophilidae) of Greece, its islands and Cyprus // Studia dipterologica. Vol.12. P.255-314.

Kurina O. 2006. Three new species of Docosia Winnertz (Diptera: Mycetophilidae) from Kazakhstan // Entomologica Fennica. Vol.17. P.110-117.

Laštovka P., Ševčik J. 2006. A review of the Czech and Slovak species of Docosia Winnertz (Diptera: Mycetophilidae), with atlas of the male and female terminalia // Čas. Slez. Muz. Opava (A). Vol.55. P.1-37.

Xu H., Wu H., Yu X.X. 2003. New Chinese record of the genus Docosia with a description of a new species (Diptera, Mycetophilidae) // Acta Zootaxonomica Sinica. Vol.28. P.343-348.

Xu H., Wu H., Wang Y. 2005. Diptera: Mycetophilidae // Insect Fauna of Middle-West Quinling Range and South Mountains of Gansu Province. P.713-718.

Søli G.E.E. 1997. The adult morphology of Mycetophilidae (s. str.), with a tentative phylogeny of the family (Diptera, Sciaroidea) // Ent. Scand., Supp1.50. P.1-55. 